\title{
Electrical stimulation as a novel tool for regulating cell behavior in tissue engineering
}

\author{
Cen Chen ${ }^{1,2}$, Xue Bai ${ }^{1}$, Yahui Ding ${ }^{3,4}$ and In-Seop Lee L $^{*}$
}

\begin{abstract}
Recently, electrical stimulation as a physical stimulus draws lots of attention. It shows great potential in disease treatment, wound healing, and mechanism study because of significant experimental performance. Electrical stimulation can activate many intracellular signaling pathways, and influence intracellular microenvironment, as a result, affect cell migration, cell proliferation, and cell differentiation. Electrical stimulation is using in tissue engineering as a novel type of tool in regeneration medicine. Besides, with the advantages of biocompatible conductive materials coming into view, the combination of electrical stimulation with suitable tissue engineered scaffolds can well combine the benefits of both and is ideal for the field of regenerative medicine. In this review, we summarize the various materials and latest technologies to deliver electrical stimulation. The influences of electrical stimulation on cell alignment, migration and its underlying mechanisms are discussed. Then the effect of electrical stimulation on cell proliferation and differentiation are also discussed.
\end{abstract}

Keywords: Electrical stimulation, Tissue engineered materials, Regenerative medicine

\section{Background}

Regenerative medicine and tissue engineering are new scientific and technological undertakings of biomedicine that combine aspects of medicine, cell, and molecular biology, materials science and bioengineering, to regenerate, repair or replace tissues or organs $[1,2]$. The three key factors of regenerative medicine and tissue engineering include seed cell, scaffold, and stimulating factor [3]. Tissue engineering scaffold could deliver specific cells to the damaged site and as a medium to provide stimuli, with the help of an appropriate structure, similar composition to natural tissue. Scaffold mimic nature tissue's mechanical properties and desired biological properties, to ensure in vivo support, optimum diffusion of nutrients, and encourage cellular communication $[4,5]$, which is an indispensable part of tissue engineering. Seed cell include non-stem cells and stem cells. The non-stem cells includes: Schwann cells (SCs), osteoblasts, fibroblast, and endothelial cells (ECs); the stem

\footnotetext{
* Correspondence: inseop@yonsei.ac.kr

${ }^{5}$ Institute of Natural Sciences, Yonsei University, 134 Shinchon-dong,

Seodaemoon-gu, Seoul 03722, Republic of Korea

Full list of author information is available at the end of the article
}

cells can be divided into two types: (1) adult stem cell: Adipose derived stem cells and muscle derived stem cells; and (2) non-adult stem cell: Embryonic stem cells (ESCs), neural stem cells (NSCs) and bone mesenchymal stem cells (BMSCs) [6]. Stem cells that possess strong self-renewal and multilineage differentiation potential [7], in cases better than non-stem cells. A cell-seeded scaffold is implanted in the patient, and then the cell will produce the new tissue, is the pillars of tissue engineering $[8,9]$. Providing seed cell for damaged or lost organs and tissues are the core of tissue engineering [10]. Rapid and complete regeneration of tissue or organs is a very challenging problem because transplanted cells are easily lost in host tissues and have low survival rates [11, 12]. Furthermore, if defective cells migrating to the wound site will lead to a more severe condition [13]. The loss of cellular function at the donor site and uncontrollable differentiation are limitations for the use of stem cell transplantation in regenerative medicine [13-15]. Thus they require the manipulation of cell behavior in vitro and in vivo, including cell proliferation, migration, differentiation, and other cellular processes [16, 17]. The choice of scaffold material, the surface topography of the

(c) The Author(s). 2019 Open Access This article is distributed under the terms of the Creative Commons Attribution 4.0 International License (http://creativecommons.org/licenses/by/4.0/), which permits unrestricted use, distribution, and 
scaffold, and the additional stimulating factors can manipulate cell behavior [18-21].

To date, several studies have demonstrated that both biochemical and biophysical cues could influence cell behaviors [17, 22, 23]. Different forms of stimulating factors can induce cell proliferation, differentiation, to complete tissue repair, inappropriate ES could cause cell death or no effect [24]. As a result select suitable stimulate factor could maximize the repair effect [25]. Biochemical cues include supplying chemical reagents [26] and performing chemical surface modification on scaffolds [27]. On the one side, adding growth factors, surface-immobilised biosignals, cytokines, and small molecule drugs would be immediately diluted by blood or metabolized by organisms. On the other side, the surface fixation methods of chemical reagents is also not perfect, methods such as silanization or co-precipitation are complexity and low efficiency, requiring more surface treatment to improve connection efficiency [28] and increasing the deposition rate [29]. Biophysical cues involve surface topography, substrate stiffness, compression and stretching, electric or magnetic fields, ultrasound stimulation, and photostimulation [30-34]. Biophysical cues have the advantages of costeffectiveness, long life, easy to characterize, and high reproducibility, which is facilitated for a large-scale operation. As a biophysical cue, electrical stimulation (ES) has been shown to effectively relieve pain, promote blood circulation, reduce vascular and skeletal muscle tension, and promote reabsorption of edema and joint fluid in the clinic [35]. Also, many studies show that ES could effectively manipulate cell behaviors in vitro and in vivo. For example, Jaatinen et al. [36] demonstrated that the mouse myoblast cell line undergoes dramatic changes in cell morphology, viability, cell structure, and cell adhesion under pulsed monophasic currents. Kumar et al. [37] showed that the cell proliferation and osteogenic differentiation of preosteoblast could favourably be regulated under dynamic electric field conditions. Besides, with the specific parameter of ES, the neurite outgrowth of NSCs could be improved [19], and the differentiation of NSCs could also be matipulated [38]. In the human body, every cell subjected to some form of stimulation, local bioelectrical signals affect cells in a variety of tissues [39]. Indeed, providing ES is a considerable method based on recent research. ES triggers the cells themselves to deliver signals through intrinsic pathways, consequently leads to direct cell activities, including migration, differentiation, and proliferation, etc. Meanwhile, ES can be used synergistically with other techniques, reducing the cost of the whole process, has the potential of alleviating some of the problems that currently prevail in tissue engineering and regenerative medicine [17, 40-42].
Here, we provide an overview of the recent developments of ES in tissue engineering, for better application in regenerative medicine and tissue engineering. The main part of the review is organized into three parts: (1) summarized the conductive materials that can be applied to tissue engineering scaffolds, including types and their advantages and disadvantages. (2) Three methods of providing ES include direct coupling, capacitive coupling, and using an electromagnetic field, and their advantages and disadvantages. (3) The specific regulation of ES on cell behaviors include cell alignment, migration and its underlying mechanisms, proliferation and differentiation. Comprehensively demonstrate the potential that ES has for tissue engineering.

\section{Different materials and methods to deliver ES}

Tissue engineering attempts to imitate the structure and function of the tissues or organs through the use of engineered scaffolds, which optimize the response of cell-biomaterials and mimic the native environment [43]. ES has received considerable attention to influence cellular or tissue behaviors as stimulation factor of tissue engineering [44]. As a bridge to deliver ES, scaffolds need to meet requirements: excellent biocompatibility, prominent electrochemical performance, and no byproduct generation [45].

\section{Materials to deliver electrical stimulation}

To provide ES for tissue regeneration or functional recovery, a number of materials have been developed to make scaffolds. To date, metallic biomaterials include platinum, and gold is increasingly used in medical applications due to their high mechanical strength, long-term stability, good conductivity, and biocompatibility [46]. However, except noble metals, most metallic materials are easily oxidized, and present weak corrosion resistance $[47,48]$, the release of metal ion may also cause allergies or carcinogenesis. Surface modification of metallic materials is considered to be an effective method to solve the above problems, include preparation of coatings, and covalent chemical conjugation of bioactive molecules [48]. Conducting polymers, such as poly (3,4-ethylene dioxythiophene), polyaniline, polypyrrole (PPy) have been studied as possible candidates [49]. Although the cracks or delamination of conducting polymers under long-term stimulation restrict the electrode performance, cross-link with a specific agent or in-situ polymerization of the conjugated polymer improving the physical stability while allowing the exploration of their superior properties $[50,51]$. Carbon materials such as graphene, carbon nanotubes and carbon aerogels have excellent electrical properties and the ability to be easily bio-functionalized, as well as drug loadings [52-54]. However, the biocompatibility of carbon relative 
materials is still a significant challenge. Scientists have modified carbon relevant materials to eliminate defects. Depositing and fixing graphene can avoid the damage to cells due to direct contact interaction and wrapping mechanisms [55]. The direct exposure of the carbon nanotubes inside the body presents a high probability of detachment. The above issue was overcome by reinforcing the carbon nanotube patterns inside the biocompatible soft polymer matrix [56]. Table 1 lists the forms of different materials, the electrical conductivity and the advantages and disadvantages.

\section{Methods to deliver electrical stimulation and its parameters}

The methods to deliver ES can mainly divide into three types: direct coupling, capacitive coupling, and using an electromagnetic field.

Direct coupling shows in Fig. 1a. The electrodes are inserted directly into the culture medium and attached to the scaffold to deliver ES. This method is most widely used because of its easy operation. However, drawbacks are apparent such as insufficient biocompatibility of the electrode, contact with the medium lead to temperature rise, $\mathrm{pH}$ changes, and the generation of harmful byproducts [59]. Prabhakaran et al. [19] demonstrated that ES applied to the NSCs cultured on the electrospun Poly-Llactide/polyaniline fibers scaffold exhibited extended neurite outgrowth. Briefly, a silver electrode and a platinum electrode were inserted into the opposite ends of the nanofiber scaffold placed in the medium and connected to constant unipolar trapezoidal pulses. The average length of neurite extended from NSCs with stimulation were nearly $100 \%$ higher than the average length of those without ES. In other circumstances, the scaffold is used as substrate-cathode. Stewart et al. [60] induced human NSCs differentiation with a twoelectrode device, placing a platinum mesh electrode on top, and using a PPy-coated Au-mylar surface as a working electrode. ES on PPy induced hNSC to differentiate into neurons expressing $\beta$-III Tubulin (Tuj1), and a small number of glial cells expressing glial fibrillary acidic proteins, accompanied with longer neurites and significant branches.

Capacitive coupling is more biologically safe compared with direct coupling. As shown in Fig. 1b, two electrodes are placed at opposite ends to provide a uniform electric field to the cells seeded on the scaffold which locates between the electrodes. This system is non-invasive and does not require a conductive scaffold to provide uniform ES. Vaca-Gonzalez et al. [61] used a capacitive coupling system to provide chondrocytes with a $4 \mathrm{mV} /$ $\mathrm{cm}$ ES, which significantly increased the cell proliferation. When applied an $8 \mathrm{mV} / \mathrm{cm}$ ES, the glycosaminoglycan secreted by chondrocytes remained stable, which is essential to maintain tissue moisture, lubrication, and protection of articular surfaces.

The third type is inductive coupling, as shown in Fig. 1c. Inductive coupling usually uses a controllable electromagnetic field generated by a conductive coil placed around the cell culture system, called pulsed electromagnetic field stimulation (PEMF). The stimulus is transmitted by the pulse to mimic the natural potential transfer in the human body [40]. PEMF provide potential near the target cell, rather than directly apply ES to the cells. The main drawback of PEMF treatment is taking time and resource consumption. For example, some therapies

Table 1 The forms, electrical conductivity, advantages and disadvantages of different materials

\begin{tabular}{|c|c|c|c|c|}
\hline Materials & Forms & Electrical conductivity & Advantages & Disadvantages \\
\hline Platinum-gold alloy [46] & Discs & $\begin{array}{l}\text { Gold } 4.52 \times 10^{7} \mathrm{~S} / \mathrm{m} \\
\text { Platinum } 9.6 \times 10^{6} \mathrm{~S} / \mathrm{m}\end{array}$ & $\begin{array}{l}\text { High mechanical strength, } \\
\text { long-term stability, good } \\
\text { biocompatibility and good } \\
\text { corrosion resistance }\end{array}$ & $\begin{array}{l}\text { Expensive, cell death caused } \\
\text { by ion release }\end{array}$ \\
\hline Magnesium (Mg) alloys [48] & Discs & $\approx 2 \times 10^{7} \mathrm{~S} / \mathrm{m}$ & $\begin{array}{l}\text { High strength, fracture resistance, } \\
\text { good electrical conductivity }\end{array}$ & $\begin{array}{l}\text { Poor biocompatibility; cell } \\
\text { death caused by high ion } \\
\text { release, and change of } \\
\text { local pH }\end{array}$ \\
\hline Polypyrrole [57] & Coating & $10^{2} \sim 10^{3} \mathrm{~S} / \mathrm{cm}$ & $\begin{array}{l}\text { Good compatibility and } \\
\text { support cell adhesion and } \\
\text { growth }\end{array}$ & $\begin{array}{l}\text { Rigid, insoluble and poorly } \\
\text { processable }\end{array}$ \\
\hline Polyaniline [58] & Film & $5 \sim 10 \mathrm{~S} / \mathrm{cm}$ & $\begin{array}{l}\text { Good environmental stability, } \\
\text { low cost, good biocompatibility }\end{array}$ & $\begin{array}{l}\text { Poor mechanical properties and } \\
\text { complicated manufacturing methods }\end{array}$ \\
\hline Graphene [55] & Coating & $10^{6} \sim 10^{8} \mathrm{~S} / \mathrm{m}$ & $\begin{array}{l}\text { Good mechanical properties, } \\
\text { easy bio-functionalization and } \\
\text { drug loading }\end{array}$ & Moderate toxicity \\
\hline Carbon nanotubes $[52,53]$ & $\begin{array}{l}\text { Doping with } \\
\text { other materials }\end{array}$ & $1.8 \times 10^{7} \mathrm{~S} / \mathrm{m}$ & $\begin{array}{l}\text { High mechanical resilience, } \\
\text { good support for active materials, } \\
\text { high chemical stability, elasticity }\end{array}$ & $\begin{array}{l}\text { Poor biocompatibility, poor } \\
\text { dispersion, insoluble and toxic } \\
\text { to the cells }\end{array}$ \\
\hline
\end{tabular}


A

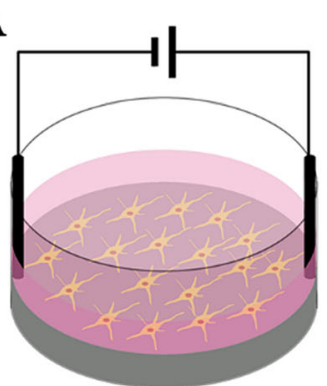

B

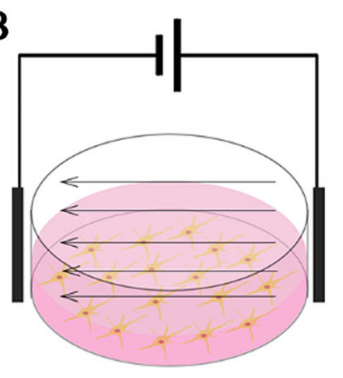

C

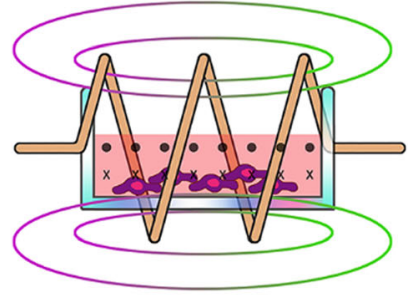

Fig. 1 Three ways to deliver electrical stimulation: (a) direct coupling, (b) capacitive coupling, and (c) inductive Reprinted with permission from reference [40]

need to last $10 \mathrm{~h}$ per day [62] or quite high voltage. Hess et al. [63] created a device using ferromagnetic core covered by the first current-carrying coil, and the culture chamber with connected silicone tube as the second coil. When applied an alternating voltage to the first coil, the second coil only influenced by the electrical potential without any interfering magnetic field or biochemical reactions. The combination of inductive coupling and high sulfated hyaluronan derivative substrate can synergistically stimulate BMSCs, the bone-related proteins (RUNX2, ALP, OPN) in BMSCs were significantly improved then cells show an osteogenic differentiation. Table 2 lists the advantages and disadvantages of each methods mentioned above.

The different parameters of ES are quite considerable for regulating cell behavior. ES can provide in the form of monophasic and biphasic, where the waveform has pulse, sinusoidal, square, triangular, and sawtooth pattern. The use of intermittent or continuous stimulation is another parameter. According to the stimulation parameters setup, monophasic stimulation is effective in polarizing the target tissue [65] but may produce reactive oxygen species through the oxidation-reduction process due to the Faradaic reaction at the surface of a metal electrode [66]. Especially in the case of large current pulses delivered at long durations and/or high frequencies, cell damage may result from the Joule heating effect [67]. However, the impact of localized ionic or electrochemical imbalance caused by the small Faradaic impact on the experiment cannot be ignored [66]. On the contrary, biphasic stimulation may be more advantageous since it prevents the charge accumulation, generates lower levels of electrolysis products at the electrodes, outside of the limitations of monophasic stimulation and can be applied for more extended periods and at higher voltages [68-70]. For instance, biphasic stimulation is usually selected in clinical application to stimulate neural tissue, because of the few charge accumulation and toxic by-products and is less likely to cause neuronal loss [69, 71]. Monophasic stimulation can be used for short-term experiments, but longterm applications require biphasic stimulation [72, 73]. Improper stimulation parameters can lead to results that are contrary to experimental expectations. The cell migration rate is positively correlated with the intensity of ES, and is discussed in next section. For stimulus frequency, ES frequency below $1 \mathrm{kHz}$ augment cell proliferation through significantly affected the cell cycle, increasing the proportion of cells and synthesizing DNA [74]. Experiments show that ES frequency above $1 \mathrm{kHz}$ can induce cell differentiation, but must maintain low intensity [75, 76]. High intensity above $100 \mathrm{~V} / \mathrm{cm}$ can cause cell membrane electroporation, an immediate increase in intracellular $\mathrm{Ca}^{2+}$ and reactive oxygen species, then induce cell apoptosis [24, 77]. When high intensity is unavoidable, pulse electrical stimulation should be used to avoid continuous high intensity to reduce damage.

Table 2 The advantages and disadvantages of three methods of providing ES

\begin{tabular}{lll}
\hline Methods & Advantages & Disadvantages \\
\hline Direct coupling [59] & Easy operation & $\begin{array}{l}\text { Insufficient biocompatibility of the electrode, } \\
\text { contact with the medium lead to temperature } \\
\text { rise, pH changes, and the generation of } \\
\text { harmful byproducts }\end{array}$ \\
Capacitive coupling [64] & More biologically safe & $\begin{array}{l}\text { High voltage between the electrodes, } \\
\text { longer treatment time }\end{array}$ \\
Inductive coupling [62] & Mimic the natural potential \\
& $\begin{array}{l}\text { transfer in the human body, } \\
\text { does not directly touch cells }\end{array}$ & time and resource consumption \\
\end{tabular}


The effects of electrical stimulation on cell alignment and migration

By participating in tissue formation, tissue regeneration, and wound healing, directed cell migration and alignment can be very beneficial for regenerative medicine [78-81]. The ability to regulate cell migration and alignment would be an invaluable asset for regenerative medicine. The mechanisms underneath the cell alignment and migration are thought to be responsible for these effects, including voltage-gated ion channels, Gprotein coupling receptors, integrins, cell polarization, and endogenous electric fields [82]. In literature, ES as the physical methods has attracted much attention because it can activate specific signaling pathways in cells near the cathode or anode and induce cell migration and alignment [83].

\section{The effects of electrical stimulation on cell alignment}

Numerous methods are capable of inducing cell migration and alignment by external factors, such as the addition of bioactive factors, providing individual surface patterns, and studies have shown that physical methods ES over all other techniques to guide cell migration and alignment [17, 41, 84].

ES has a significant effect on cell alignment and redirect random cells to be aligned, the direction of cell alignment changes gradually as the direction of the ES changes [84-86]. Some types of cell are aligned perpendicular to the direction of the electric field vectors to minimize the field gradient across the cell, such as cardiac adipose tissue-derived progenitor cells [18], endothelial progenitor cells [87], vascular ECs [77], BMSCs [88], adipose-derived stromal cells [89], etc. At the same time, some cells are aligned parallel to the field vectors due to the ES causes rearrangement of the cell cytoskeleton, such as ventricular myocytes [20], cardiomyocytes [86], myoblasts [85], PC-12 cells [90], obsteoblasts [84], etc. The ES intensity usually $<10 \mathrm{~V} / \mathrm{cm}$, and the cells aligned better with the ES intensity increased, but the cell activity is relatively decreased [77, 87, 91].

In the presence of $100 \mathrm{~mA}$ monophasic ES, the osteoblasts elongation and proliferation were mainly reliant on the ES, whereas the topographical features played a minor role [84]. In our present study [90], perpendicular electrical field vectors from the pattern may reorientate the PC-12 cell alignment, while parallel vectors could further increase neuritis extension compared with perpendicular vectors. On the contrary, some types of cell are aligned perpendicular to the vectors under ES. The murine adipose-derived stromal cells exhibited a constant perpendicular alignment with the field vectors [89]. BMSCs consistent perpendicular alignment to the field vectors [88]. The long axis of cobblestone-like ECs transformed into highly ordered, perpendicular to the field vectors with applied ES, then the cell morphology presents similarly to the inner surface topography of the blood vessel, which shows excellent potential in angiogenesis [77].

\section{The effects of electrical stimulation on cell migration}

As well as cell alignment, ES plays a significant role in cell migration. The directional migration of cells in response to ES is called electrotaxis [77]. The guiding effect of ES on cell migration also differs depending on the cell type. Among different types of cell, NSCs [92], macrophages [93], mouse neural precursor cells (NPCs) [94], osteoblasts [95] and endothelial progenitor cells [87] toward the cathode [20, 89, 92, 96], BMSCs [97], human dermal fibroblasts [98] and SCs [99, 100] toward the anode. Reversal of the ES polarity reversed the migration direction of cells $[87,92]$. The ES intensity can stimulate cell migration from a minimum of $0.1 \mathrm{~V} / \mathrm{cm}$ to a maximum of $12 \mathrm{~V} / \mathrm{cm}$ and did not cause any significant damage to cells, did not affect cell phenotype or the differentiation potential [101-103]. At the same time, cells showed gradually increased migration rate and distance with higher ES strength [101, 104, 105].

As NPCs shows a cathodal migration, Liu et al. [103] demonstrated that reversing the ES direction resulted in a reversed direction of NPCs migration. This behavior is beneficial to long-distance migration of neural cells for nerve repair. ES also directs some types of cell migrate to the anode, such as BMSCs $[97,106]$, human dermal fibroblasts [37] and SCs [99, 100, 107]. Forciniti et al. [100] indicated an increase in average displacement of the SCs to anodal with $0.5 \mathrm{~V}$ to $1 \mathrm{~V} \mathrm{ES}$, which is of great value in optimizing conductive polymers for different biomedical applications such as nerve repair. Moreover, even different cell lines of the same specie have different responses to ES in the migration. Li et al. [108] demonstrated different cell lines of non-small cell lung cancer cells (H460, and H1299) showed great different in migration direction, while H460 migrated toward cathode, H1299 exhibited anodal migration. This discovery has led to a better understanding of the mechanism of cancer, which is beneficial for cancer therapy.

mASCs exhibited a positive correlation between cell migration rate and ES intensity (from $1 \mathrm{~V} / \mathrm{cm}$ to $10 \mathrm{~V} /$ $\mathrm{cm})$ [89]. The same performance showed in human BMSCs, as the ES intensity is above the physiological level, the migration rate increases while physiological levels of ES do not affect cell motility, this behavior may be essential for maintaining transplanted cells at the lesion site $[88,105]$. Different research groups have conflict results in the same cell type. Forciniti et al. [100] showed ES conditions (from 0 to $0.5 \mathrm{~V}$ ) produced a significant increase in SCs migration rate but did not affect migration direction. Different from others, Li 
et al. [99] demonstrated the ES did not significantly affect the SCs migration speed, but as the ES intensity increases from $50 \mathrm{mV} / \mathrm{mm}$ to $200 \mathrm{mV} / \mathrm{mm}$, the orientation and displacement of the anode migration increase significantly.

\section{Mechanism of ES on cell migration}

The specific mechanism leading to electrotaxis is still unclear. Many factors may be included, such as endogenous microenvironment, ion channels, membrane receptors, transport proteins, and competing signal pathways such as Wnt/GSK3 $\beta$ and TGF $\beta 1 /$ ERK/NF- $k B$ [109-111]. According to the literature, the main mechanism involved in ES induced cell migration is shown in Fig. 2.

The importance of epidermal growth factor receptors (EGFR) in ES induced cell migration has attracted the attention of numerous scientists [77, 87, 112]. ES regulates downstream growth factors and cytokine production through a feedback mechanism by EGFR. Asymmetric expression of EGFR in front of and behind cells activates signaling pathways and leads to cell migration [112, 113]. Pilipos et al. [114] demonstrated that blockade of EGFR via erlotinib significantly attenuate NPCs electrotaxis. EGFR activation stimulates several signaling pathways, including MAPK-ERK1/2 and PI3K/ Akt pathway. MAPK-ERK1/2 are generally involved in signal transduction from extracellular sources in different signaling pathways. Downstream protein ERK1 and ERK2 are fully activated by phosphorylation of MEK, which is involved in cell migration. Hammerick et al. [89] proved that inhibiting the MAPK pathway leading to migration inhibited suggests the participation of this pathway in mASCs electrotaxis. It has been reported that static monophasic ES can regulate epithelial cell proliferation and migration by activating the MAPK signaling cascade ERK1/2 [115].

The other and the most critical pathway is the PI3K/ Akt signaling pathway, which has been mostly explored in the cellular response to ES. ES significantly increase the expression of downstream protein PIP3 and phosphorylation of Akt, at the same time, induce the asymmetric distribution of PIP3 and cytoskeletal proteins migrate toward cathode [113, 116]. Meng et al. [116] exhibited the cathode migration of NPCs under ES needed the activation of the PI3K signal pathway. Pharmacological inhibition or genetic disruption of PI3K/Akt pathway will inhibit the electrotaxis, then applied ES increases Akt phosphorylation and PIP3 fluorescence, demonstrate the importance of the PI3K/Akt pathway in ES driven directed migration of NPCs. PTEN is a phosphatase that inhibits PI3K signaling transduction including Akt. Zhao et al. [117] demonstrated genetic disruption of PTEN within keratinocyte enhanced ES induced ERK and Akt phosphorylation, cell performed a significantly higher directionality compared with

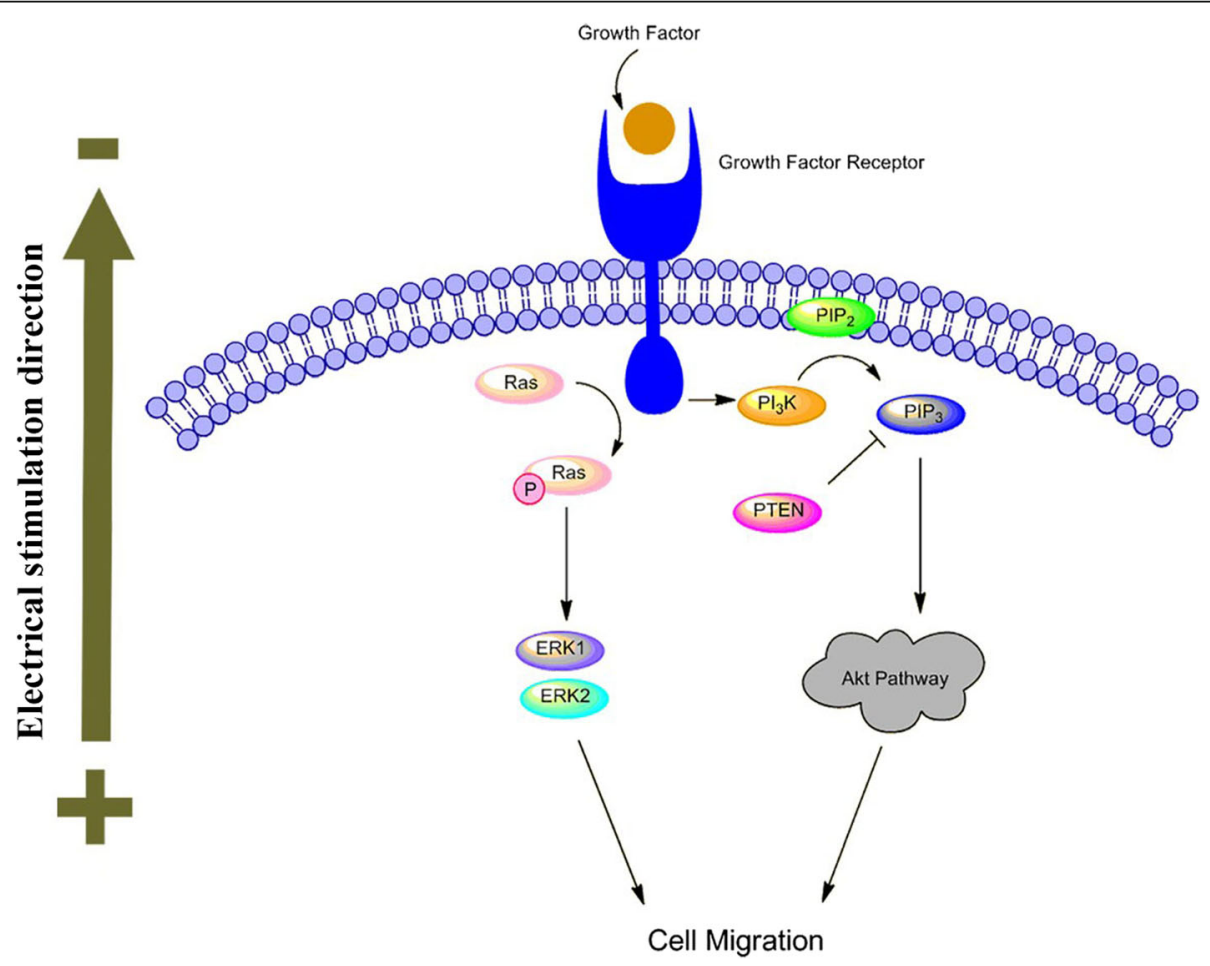

Fig. 2 Mechanism of ES-induced cell migration 
controls. This result supports the antagonistic relationship between PI3K and PTEN.

In addition to signal pathways, ion channels such as voltage-gated $\mathrm{Ca}^{2+}$ channels is a vital part of membrane polarization and cell response during ES [118]. All living cells have a transmembrane potential. The current induces a flow of ions $\left(\mathrm{Na}^{+}, \mathrm{Cl}^{-}, \mathrm{K}^{+}, \mathrm{Ca}^{2+}\right.$, etc.) by ion channels and transporters [16]. In response to ES, intracellular molecular and transport channel polarization, then ion flow takes place and trigger cytoskeleton changes to direct cell migration, in consequence, the calcium influx contribute to persistent cell migration towards cathode [101]. In the review of Balint et al. [40], the ES effect will be impaired or completely blocked if block the calcium channels, intracellular store and the calmodulin by verapamil and nifedipine, TMB-8, W-7, respectively. Zhao et al. [102] reported that a $115 \mathrm{~V} / \mathrm{m}$ monophasic ES could cause a calcium influx mediated NPCs mobility improved and cathodal migration.

\section{The effects of electrical stimulation on cell proliferation and differentiation}

In addition to the impact on the migration, ES also plays a significant role in influencing proliferation and guiding differentiation $[50,119,120]$. A major challenge in regenerative medicine is to compensate cells that lost as a result of injury or disease [15]. For instance, after excessive cell loss, most tissues produce scars, such as fibrous collagen scars in the heart, causing an ischemic environment and limiting oxygen delivery [121]. However, the inevitable problems are the difficulty in harvesting sufficient cells for implantation. In these circumstances, the capabilities of proliferation and multilineage differentiation of seed cells have attracted much attention [122]. Table 1 summarizes the specific conditions of ES to induce cell proliferation and differentiation.

\section{The effects of electrical stimulation on cell proliferation}

Proper ES can promote cell proliferation, usually under continuous stimulation of $<1 \mathrm{~V} / \mathrm{cm}[37,95,120]$. Within the ES intensity range the cell proliferation rate increases with increasing intensity [95]. Preosteoblasts [123], obsteoblasts [37], unrestricted somatic human stem cells [124], human umbilical vein ECs [125], NSCs [126], human dermal fibroblasts [127] exhibited 0.2 to 1.5 times proliferation, with increasing cellular metabolic activity, and do not affect cell phenotype [123]. High-intensity ES of $>100 \mathrm{~V} / \mathrm{cm}$ is also favorable for cell proliferation in a short period $(<1 \mathrm{~ms})$ single stimulation, but excessively high intensity leads to cell death [128].

Shao et al. [17] demonstrated that in the presence of $100 \mathrm{~mA}$ direct current (DC), the viability of osteoblasts did not affect, and the degree of proliferation increased significantly compared with no stimuli group and other current stimuli groups. This finding indicates that proper ES can be used for bone regeneration and fracture healing. Zhu et al. [126] revealed that compared with the control group, NSCs proliferation was increased $35 \%$ with ES, which condition is $100 \mu \mathrm{A}$ and pulse rates of $100 \mathrm{~Hz}$ with $100 \mu \mathrm{sec}$ duration for $24 \mathrm{~h}$. A possible cause is that ES upregulates the proliferation of cell nuclear antigen, which is a DNA polymerase-associated protein, and activate extracellular signal-regulated kinases 1 and 2 pathways involved in transduction of proliferative signals. Meanwhile, the differentiation potential of NSCs has not been affected by the promotion of proliferation. In the study of Sun et al. [129] SCs underwent a remarkable degree of proliferation under ES $(100 \mathrm{mV} /$ $\mathrm{cm}, 1 \mathrm{~h}$ per day) than without ES, especially in day 5 . It might because ES promoted SC myelin gene expression and neurotrophin secretion, then led to SCs proliferation. This result indicated the promising potential of ES on peripheral nerve repair and regeneration. Kapeller et al. [119] pointed out that with $1 \mu \mathrm{A} \mathrm{DC}$ stimuli, cardiomyocytes showed better proliferation behavior with no morphological changes in vitro. At the same time, ES also affects matrix metalloproteinases (MMP) in cardiomyocytes, which involved to keep the balance between matrix synthesis and degradation. It shows that ES has a certain positive effect on heart repair.

\section{The effects of electrical stimulation on cell differentiation}

Cell differentiation based therapy provides a promising approach for regeneration medicine. Short-term (several minutes), low-intensity $(0.06 \sim 6 \mathrm{~V} / \mathrm{cm})$ ES can promote cardiac differentiation of human induced pluripotent stem cells, muscle precursor cells, with the formation of embryoid bodies [130, 131]. Neural progenitor cells, neural precursor cells, and NSCs can differentiate into neurons instead of glial cells under ES [102, 106, 132]. The stimulation intensity is basically $<2 \mathrm{~V} / \mathrm{cm}$ and sustain more than 7 days. The differential medium can appropriately added with FBS, retinoic acid, and nerve growth factor. ES can induce bone marrow stromal cells, BMSCs, MC3T3-E1 cells osteogenic differentiation instead of cartilage, stimulation intensity should be $<2 \mathrm{~V} / \mathrm{cm}$ and sustain $14 \sim 28$ days, the medium need to add dexamethasone in most cases $[6,63,120,133-135]$. Therefore, the application of ES could provide a valid approach to induce cell differentiation in tissue engineering.

Hernández et al. [131] demonstrated human induced pluripotent stem cells (Foreskin)-2 cell line exhibit cardiac differentiation under ES $(65 \mathrm{mV} / \mathrm{mm}$ or $200 \mathrm{mV} /$ $\mathrm{mm}$, biphasic current pulses), by significantly increased the expression of cardiac transcription factors $n k x 2.5$ and $t b x 5$, as well as the cardiac contractile muscle 
Table 3 The specific conditions of ES to induce cell proliferation and differentiation

\begin{tabular}{|c|c|c|c|}
\hline Cell type & Type of ES & Electrical parameters & Major findings \\
\hline Osteoblast & DC & $100 \mathrm{~mA}$ & $\begin{array}{l}\text { Celluar proliferation, elongation were } \\
\text { improved }\end{array}$ \\
\hline NSCs & Biphasic current pulses & $\begin{array}{l}100 \mu \mathrm{A}, 100 \mathrm{~Hz} \text { with } 100 \mu \mathrm{sec} \\
\text { duration }\end{array}$ & $\begin{array}{l}\text { NSCs proliferation was promoted } \\
\text { associating with upregulated } \\
\text { neuronal gene expression level and } \\
\text { increased microtubule-associated } \\
\text { protein } 2\end{array}$ \\
\hline Cardiomyocytes & DC & $\sim 1 \mu \mathrm{A}$ & $\begin{array}{l}\text { Enhances proliferation with no } \\
\text { morphological changes in vitro, } \\
\text { modulate the expression of MMPs } \\
\text { and TIMPs in vitro and in vivo }\end{array}$ \\
\hline $\begin{array}{l}\text { Human induced pluripotent stem } \\
\text { cells (Foreskin)-2 cell line }\end{array}$ & Biphasic current pulses & $\begin{array}{l}65 \mathrm{mV} / \mathrm{mm} \text { or } 200 \mathrm{mV} / \mathrm{mm} \text { for } 5 \\
\mathrm{~min}, 1 \mathrm{~Hz} \text {, and } 1 \mathrm{~ms} \text { pulse width }\end{array}$ & $\begin{array}{l}\text { The cell showed cardiac } \\
\text { differentiation with increased the } \\
\text { expression of NKX } 2.5 \text { and TBX5, as } \\
\text { well as the proteins ACTC1, TNNT2, } \\
\text { MYH7, and MYL7 }\end{array}$ \\
\hline Human ESCs & N/A & $6.6 \mathrm{~V} / \mathrm{cm}, 1 \mathrm{~Hz}$, and $2 \mathrm{~ms}$ pulses & $\begin{array}{l}\text { Upregulation of gene expression } \\
\text { including HCN1, MLC2V, SCN5A, } \\
\text { SERCA, Kv4.3, and GATA4; cellular } \\
\text { elongation, and an increase in the } \\
\text { proportion of ventricular-like hESC- } \\
\text { derived cardiomyocytes }\end{array}$ \\
\hline Mouse bone marrow stromal cells & Rectangular pulse & $100 \mathrm{mV}, 10 \mathrm{~Hz}, 2.0 \mathrm{~ms}, 30 \mathrm{~min}$ & $\begin{array}{l}\text { Induced the differentiation of mouse } \\
\text { BMSCs into neural cells with } \\
\text { enhanced neurogenin2 (Ngn2) } \\
\text { expression }\end{array}$ \\
\hline SCs \& PC12 cell & N/A & $100 \mathrm{mV} / \mathrm{cm}, 1 \mathrm{~h}$ & $\begin{array}{l}\text { Promote SCs proliferation, and } \\
\text { promoted PC12 cell differentiation } \\
\text { into SCS and axonal extension }\end{array}$ \\
\hline $\begin{array}{l}\text { Mouse embryonic osteoblast } \\
\text { precursors Mc-3 T3-E1 }\end{array}$ & Rectangular pulses & $\begin{array}{l}200 \mathrm{mV} / \mathrm{cm}, 1 \mathrm{~Hz} \text { to } 100 \mathrm{kHz}, 30 \\
\mathrm{~min}\end{array}$ & $\begin{array}{l}100 \mathrm{~Hz} \text { could up-regulate the mRNA } \\
\text { levels of collagen I, collagen II and } \\
\text { Runx2, accelerate cells differentiation } \\
\text { and proliferation, down-regulate the } \\
\text { mRNA levels of osteopontin (OPN). } 1 \\
\mathrm{~Hz} \text { to } 10 \mathrm{~Hz} \text { could improve calcium } \\
\text { deposition in the intracellular matrix. }\end{array}$ \\
\hline BMSCs & N/A & $20 \mathrm{mV} / \mathrm{cm}, 60 \mathrm{kHz}$ & $\begin{array}{l}\text { An increase in ALP and col1 } \\
\text { transcript, and NADH, FAD, lipofuscin } \\
\text { was detected, improved hMSC } \\
\text { differentiation potential to bone }\end{array}$ \\
\hline
\end{tabular}

proteins ACTC1, TNNT2, MYH7, and MYL7, compared with the unstimulated control group. In the study of Chan et al. [130], human ESCs cultured in the presence of ES $(6.6 \mathrm{~V} / \mathrm{cm}, 1 \mathrm{~Hz}$, and $2 \mathrm{~ms}$ pulses) showed an increase in the proportion of ventricular-like cardiomyocytes, by significant upregulation of cardiac-specific gene expression including hcn1, $m l c 2 v, \operatorname{scn} 5 a$, serca, kv4.3, and gata4. Matsumoto et al. [135] induced the differentiation of mouse bone marrow stromal cells into neural cells using ES $(10 \mathrm{~Hz}, 100 \mathrm{mV}, 2.0 \mathrm{~ms}, 30 \mathrm{~min}$, rectangular pulse). Neurogenin2 was detected as increased expression through the $\beta$-catenin signaling pathway after $E S$, which is involved in neural differentiation and inhibits astrocytic differentiation. Sun et al. [129] demonstrated ES $(100 \mathrm{mV} / \mathrm{cm}, 1 \mathrm{~h})$ could induce PC-12 cell differentiation into $\mathrm{SCs}$ and synaptic elongation even without nerve growth factor treatment, which is a kind of nerve growth regulator that promotes both neuron nutrition and neurite outgrowth.

In the study of Wang et al. [120] ES $(200 \mathrm{mV} / \mathrm{cm}, 1 \mathrm{~Hz}$ to $100 \mathrm{kHz}, 30 \mathrm{~min}$ ) promote MC3T3-E1 cells osteogenic differentiation via examined alkaline phosphatase activity. During stimulation, $100 \mathrm{~Hz}$ could up-regulate the mRNA levels of collagen I, collagen II, and RUNX2, which are osteosis-related genes. On the other hand, 1 $\mathrm{Hz}$ to $10 \mathrm{~Hz}$ could improve calcium deposition in the intracellular matrix, which contribute to treat the bone fracture and bone nonunion. Hronik-Tupaj et al. [6] demonstrated ES $(20 \mathrm{mV} / \mathrm{cm}, 60 \mathrm{kHz})$ improved hMSC osteogenic differentiation potential based on calcium deposition, because of the two-fold increase of alkaline phosphatase and collagen type 1 .

Table 3 The specific conditions of ES to induce cell proliferation and differentiation. 


\section{Summary}

In this review, we have highlighted the effects of ES as a physical stimulator on cellular behavior for the purposes of applying to regenerative medicine and tissue engineering. In most cases, ES facilitates cell proliferation and differentiation, enhance cell cathode migration and alignment to field vectors, and mainly through EGFR, PI3K and $\mathrm{Ca}^{2+}$ related mechanism. ES can be delivered through tissue engineering scaffolds made of metallic biomaterials, conducting polymers, or carbon materials, the main methods are direct coupling, capacitive coupling, and using an electromagnetic field.

In the future, the combination of specific material/ structure and ES will offer many advantages over other types of stimulations and allow for precise cellular regulation. Developing safe and effective partition-type scaffold combine with ES that can distinguish different areas to perform different stimulation still requires some challenges to be overcome. Although still in its early stages, the field of ES is rapidly evolving, and new nextgeneration regenerative medicine and tissue engineering will make it possible to take advantage of ES. Studying the low risk ES method for wearable application is also a future direction. With increasing research, electrical stimuli have the potential to play a significant role in tissue engineering and regenerative medicine.

\section{Acknowledgements}

This research was supported by Natural Science Foundation of Zhejiang Province (LY20E010006, LQ16E020006), National Natural Science Foundation of China (51502265), Basic Science Research Program through the National Research Foundation of Korea (NRF) funded by the Ministry of Education, Republic of Korea (2015R1D1A1A09058875), Opening Project of Zhejiang Provincial Top Key Discipline of Pharmaceutical Sciences, and the Project of Administration of Traditional Chinese Medicine of Zhejiang Province of China (No. 2018ZB011)

\section{Authors' contributions}

$\mathrm{CC}$ is responsible for modifying the manuscript. XB was responsible for initial literature review and writing of the manuscript. YHD made some pertinent suggestions. ISL contributed to the completion of the manuscript. Both authors read and approved the final manuscript.

\section{Funding}

Not applicable.

\section{Availability of data and materials \\ Not applicable.}

Ethics approval and consent to participate

Not applicable.

\section{Consent for publication}

Not applicable.

\section{Competing interests}

The authors declare that they have no competing interests.

\section{Author details}

${ }^{1}$ College of Life Sciences and Medicine, Zhejiang Sci-Tech University, Hangzhou 310018, People's Republic of China. 'Zhejiang Provincial Key Laboratory of Silkworm Bioreactor and Biomedicine, Hangzhou 310018, People's Republic of China. ${ }^{3}$ Department of Cardiology, Zhejiang Provincial
People's Hospital, Hangzhou 310014, People's Republic of China. ${ }^{4}$ People's Hospital of Hangzhou Medical College, Hangzhou 310014, People's Republic of China. ${ }^{5}$ Institute of Natural Sciences, Yonsei University, 134 Shinchon-dong, Seodaemoon-gu, Seoul 03722, Republic of Korea.

Received: 5 August 2019 Accepted: 27 November 2019

Published online: 05 December 2019

\section{References}

1. Tatullo M, Marrelli M, Paduano F. The regenerative medicine in oral and maxillofacial surgery: the most important innovations in the clinical application of mesenchymal stem cells. Int J Med Sci. 2015;2(1):72-7.

2. Mason C, Dunnill P. A brief definition of regenerative medicine. Regen Med. 2008;3(1):1-5

3. Bhardwaj N, Devi D, Mandal BB. Tissue-engineered cartilage: the crossroads of biomaterials, cells and stimulating factors. Macromol Biosci. 2015;15(2): 153-82.

4. Gupta P, Adhikary M, Kumar M, Bhardwaj N, Mandal BB. Biomimetic, osteoconductive non-mulberry silk fiber reinforced tricomposite scaffolds for bone tissue engineering. ACS Appl Mat Interfaces. 2016;8(45):30797-810.

5. Mondschein RJ, Kanitkar A, Williams CB, Verbridge SS, Long TE. Polymer structure-property requirements for stereolithographic $3 \mathrm{~d}$ printing of soft tissue engineering scaffolds. Biomaterials. 2017;140:170-88.

6. Hronik-Tupaj M, Rice WL, Cronin-Golomb M, Kaplan DL, Georgakoudi I. Osteoblastic differentiation and stress response of human mesenchymal stem cells exposed to alternating current electric fields. Biomed Eng Online. 2011;10(1):9.

7. Li C, Wei G, Gu Q, Wen G, Qi B, Xu L, et al. Donor age and cell passage affect osteogenic ability of rat bone marrow mesenchymal stem cells. Cell Biochem Biophys. 2015;72(2):543-9.

8. Guillot PV, Cui WN, Polak DJ. Stem cell differentiation and expansion for clinical applications of tissue engineering. J Cell Mol Med. 2010;11(5):935-44.

9. Breuls RG, Jiya TU, Smit TH. Scaffold stiffness influences cell behavior: opportunities for skeletal tissue engineering. Open Orthop J. 2008;2(2):103-9.

10. Bianco P, Robey PG. Stem cells in tissue engineering. Nature. 2014; 414(6859):639-53.

11. Ma F, Xiao Z, Chen B, Hou X, Han J, Zhao Y, et al. Accelerating proliferation of neural stem/progenitor cells in collagen sponges immobilized with engineered basic fibroblast growth factor for nervous system tissue engineering. Biomacromolecules. 2014;15(3):1062-8.

12. Chen G, Qi Y, Niu L, Di T, Zhong J, Fang T, et al. Application of the cell. sheet technique in tissue engineering. Biomed Rep. 2015;3(6):749-57.

13. Min Z. Electrical fields in wound healing-an overriding signal that directs cell migration. Semin Cell Dev Biol. 2009;20(6):674-82.

14. Li W, Guan T, Zhang X, Wang Z, Wang M, Zhong W, et al. The effect of layer-by-layer assembly coating on the proliferation and differentiation of neural stem cells. ACS Appl Mater Interfaces. 2015;7(5):3018-29.

15. Kobolak J, Dinnyes A, Memic A, Khademhosseini A, Mobasheri A. Mesenchymal stem cells: identification, phenotypic characterization, biological properties and potential for regenerative medicine through biomaterial micro-engineering of their niche. Methods. 2016;99:62-8.

16. Love MR, Palee S, Chattipakorn SC, Chattipakorn N. Effects of electrical stimulation on cell proliferation and apoptosis. J Cell Physiol. 2018;233(3): 1860-76.

17. Ding S, Kingshott P, Thissen H, Pera M, Wang PY. Modulation of human mesenchymal and pluripotent stem cell behavior using biophysical and biochemical cues: a review. Biotechnol Bioeng. 2017;1 14(2):260-80.

18. Llucià-Valldeperas A, Sanchez B, Soler-Botija C, Gálvez-Montón C, Prat-Vidal C, Roura S, et al. Electrical stimulation of cardiac adipose tissue-derived progenitor cells modulates cell phenotype and genetic machinery. J Tissue Eng Regen Med. 2015;9(11):E76-83.

19. Prabhakaran MP, Ghasemimobarakeh L, Jin G, Ramakrishna S. Electrospun conducting polymer nanofibers and electrical stimulation of nerve stem cells. J Biosci Bioeng. 2011;112(5):501-7.

20. Radisic M, Park H, Shing H, Consi T, Schoen FJ, Langer R, et al. Functional assembly of engineered myocardium by electrical stimulation of cardiac myocytes cultured on scaffolds. Proc Natl Acad Sci U S A. 2004;101(52): 18129-34.

21. Frelinger AL 3rd, Torres AS, Caiafa A, Morton CA, Berny-Lang MA, Gerrits AJ, et al. Platelet-rich plasma stimulated by pulse electric fields: platelet 
activation, procoagulant markers, growth factor release and cell proliferation. Platelets. 2016;27(2):128-35.

22. Jeon O, Lee K, Alsberg E. Spatial micropatterning of growth factors in $3 d$ hydrogels for location-specific regulation of cellular behaviors. Small. 2018; 14(25):1800579.

23. Wang Z, Qing Q, Chen X, Liu CJ, Luo JC, Hu JL, et al. Effects of scaffold surface morphology on cell adhesion and survival rate in vitreous cryopreservation of tenocyte-scaffold constructs. Appl Surf Sci. 2016;388:223-7.

24. Nuccitelli R, Lui K, Kreis M, Athos B, Nuccitelli P. Nanosecond pulsed electric field stimulation of reactive oxygen species in human pancreatic cancer cells is ca (2+)-dependent. Biochem Biophys Res Commun. 2013;435(4):580-5.

25. Ji WC, Zhang XW, Qiu YS. Selected suitable seed cell, scaffold and growth factor could maximize the repair effect using tissue engineering method in spinal cord injury. World J of Exp Med. 2016;6(3):58-62.

26. Choi JS, Yoon HI, Lee KS, Choi YC, Yang SH, Kim I-S, Cho YW. Exosomes from differentiating human skeletal muscle cells trigger myogenesis of stem cells and provide biochemical cues for skeletal muscle regeneration. J Control Release. 2016;222:107-15.

27. Prabhakaran MP, Venugopal J, Chan CK, Ramakrishna S. Surface modified electrospun nanofibrous scaffolds for nerve tissue engineering. Nanotechnology. 2008;19(45):455102.

28. Shori D, Pandey S, Kubde R, Rathod Y, Atara R, Rathi S. To evaluate and compare the effect of different post surface treatments on the tensile bond strength between fiber posts and composite resin. J Int Oral Health. 2013; 5(5):27-32.

29. Teker D, Muhaffel F, Menekse M, Karaguler NG, Baydogan M, Cimenoglu H. Characteristics of multi-layer coating formed on commercially pure titanium for biomedical applications. Mater Sci Eng C Mater Biol Appl. 2015;48:579-85.

30. Morgan JT, Wood JA, Shah NM, Hughbanks ML, Russell P, Barakat Al, et al. Integration of basal topographic cues and apical shear stress in vascular endothelial cells. Biomaterials. 2012;33(16):4126-35.

31. Yang Y, Wang K, Gu X, Leong KW. Biophysical regulation of cell behavior - cross talk between substrate stiffness and nanotopography. Engineering (Beijing). 2017;3(1):36-54.

32. Zhang SX, Liu L, Zhao W. Targeting biophysical cues: a niche approach to study, diagnose, and treat cancer. Trends Cancer. 2018;4(4):268-71.

33. Gao J, Raghunathan VK, Reid B, Wei D, Diaz RC, Russell P, et al. Biomimetic stochastic topography and electric fields synergistically enhance directional migration of corneal epithelial cells in a mmp-3-dependent manner. Acta Biomater. 2015;12:102-12.

34. Huang X, Das R, Patel A, Nguyen TD. Physical stimulations for bone and cartilage regeneration. Regen Eng Transl Med. 2018;4(4):216-37.

35. Hernandez-Bule ML, Trillo MA, Ubeda A. Molecular mechanisms underlying antiproliferative and differentiating responses of hepatocarcinoma cells to subthermal electric stimulation. PLoS One. 2014;9(1):e84636.

36. Jaatinen L, Young E, Hyttinen J, Vörös J, Zambelli T, Demkó L. Quantifying the effect of electric current on cell adhesion studied by single-cell force spectroscopy. Biointerphases. 2016;11(1):011004.

37. Kumar A, Nune KC, Misra R. Understanding the response of pulsed electric field on osteoblast functions in three-dimensional mesh structures. J Biomater Appl. 2016;31(4):594-605.

38. Li N, Zhang Q, Gao S, Song Q, Huang R, Wang L, et al. Three-dimensional graphene foam as a biocompatible and conductive scaffold for neural stem cells. Sci Rep. 2013;3:1064.

39. Rando TA, Ambrosio F. Regenerative rehabilitation: applied biophysics meets stem cell therapeutics. Cell Stem Cell. 2018;22(3):306-9.

40. Balint R, Cassidy NJ, Cartmell SH. Electrical stimulation: a novel tool for tissue engineering. Tissue Eng Part B Rev. 2013;19(1):48-57.

41. Wang ET, Zhao M. Regulation of tissue repair and regeneration by electric fields. Chin J Traumatol. 2010;13(1):55-61.

42. Chen C, Kong XD, Lee IS. Modification of surface/neuron interfaces for neural cell-type specific responses: a review. Biomed Mater. 2015;11(1):014108.

43. Deepthi S, Jeevitha K, Sundaram MN, Chennazhi K, Jayakumar R. Chitosanhyaluronic acid hydrogel coated poly (caprolactone) multiscale bilayer scaffold for ligament regeneration. Chem Eng J. 2015;260:478-85.

44. Wang J, Tian L, Chen N, Ramakrishna S, Mo X. The cellular response of nerve cells on poly---lysine coated plga-mwcnts aligned nanofibers under electrical stimulation. Mater Sci Eng C Mater Biol Appl. 2018;91:715-26.

45. Li J, Hu H, Li H, Yao C. Recent developments in electrochemical sensors based on nanomaterials for determining glucose and its byproduct $\mathrm{H}_{2} \mathrm{O}_{2}$. J Mater Sci. 2017;52(17):10455-69.
46. Colic M, Stamenkovic D, Anzel I, Lojen G, Rudolf R. The influence of the microstructure of high noble gold-platinum dental alloys on their corrosion and biocompatibility in vitro. Gold Bull. 2009;42(1):34-47.

47. Nazeer MA, Yilgor E, Yilgor I. Intercalated chitosan/hydroxyapatite nanocomposites: promising materials for bone tissue engineering applications. Carbohydr Polym. 2017;175:38-46.

48. Hu GQ, Guan K, Lu LB, Zhang JR, Lu N, Guan YC. Engineered functional surfaces by laser microprocessing for biomedical applications. Engineering. 2018;4(6):822-30.

49. Ramasamy MS, Nikolakapoulou A, Raptis D, Dracopoulos V, Paterakis G, Lianos P. Reduced graphene oxide/polypyrrole/pedot composite films as efficient pt-free counter electrode for dye-sensitized solar cells. Electrochimi Acta. 2015;173:276-81.

50. Pires F, Ferreira Q, Rodrigues CAV, Morgado J, Ferreira FC. Neural stem cell differentiation by electrical stimulation using a cross-linked pedot substrate: expanding the use of biocompatible conjugated conductive polymers for neural tissue engineering. Biochim Biophys Acta. 2015;1850(6):1158-68.

51. DeVolder RJ, Seo Y, Kong H. Proangiogenic alginate-g-pyrrole hydrogel with decoupled control of mechanical rigidity and electrically conductivity. Biomater Res. 2017;21(1):24.

52. Zhang LL, Zhao X. Carbon-based materials as supercapacitor electrodes. Chem Soc Rev. 2009;38(9):2520-31.

53. Lee JR, Ryu S, Kim S, Kim BS. Behaviors of stem cells on carbon nanotube. Biomater Res. 2015;19(1):3.

54. Kim J, Kim HD, Park J, Lee ES, Kim E, Lee SS, et al. Enhanced osteogenic commitment of murine mesenchymal stem cells on graphene oxide substrate. Biomater Res. 2018;22(1):1.

55. Akhavan O. Graphene scaffolds in progressive nanotechnology/stem cellbased tissue engineering of the nervous system. J Mater Chem B. 2016; 4(19):3169-90

56. Gupta P, Lahiri D. Aligned carbon nanotube containing scaffolds for neural tissue regeneration. Neural Regen Res. 2016;11(7):1062-3.

57. Ghasemi-Mobarakeh L, Prabhakaran MP, Morshed M, Nasr-Esfahani MH, Baharvand $\mathrm{H}$, Kiani S, et al. Application of conductive polymers, scaffolds and electrical stimulation for nerve tissue engineering. J Tissue Eng Regen Med. 2011:5(4):e17-35.

58. Liu S, Wang J, Zhang D, Zhang P, Ou J, Liu B, et al. Investigation on cell biocompatible behaviors of polyaniline film fabricated via electroless surface polymerization. Appl Surf Sci. 2010;256(11):3427-31.

59. Samadian H, Zakariaee SS, Adabi M, Mobasheri H, Azami M, Faridi-Majidi R. Effective parameters on conductivity of mineralized carbon nanofibers: an investigation using artificial neural networks. RSC Adv. 2016;6(113):11908-18.

60. Stewart E, Kobayashi NR, Higgins MJ, Quigley AF, Jamali S, Moulton SE, et al. Electrical stimulation using conductive polymer polypyrrole promotes differentiation of human neural stem cells: a biocompatible platform for translational neural tissue engineering. Tissue Eng Part C Methods. 2015; 21(4):385-93.

61. Vaca-Gonzalez JJ, Guevara JM, Vega JF, Garzon-Alvarado DA. An in vitro chondrocyte electrical stimulation framework: a methodology to calculate electric fields and modulate proliferation, cell death and glycosaminoglycan synthesis. Cell Mol Bioeng. 2016;9(1):116-26.

62. Fu YC, Lin CC, Chang JK, Chen CH, Tai IC, Wang GJ, et al. A novel single pulsed electromagnetic field stimulates osteogenesis of bone marrow mesenchymal stem cells and bone repair. PLoS One. 2014;9(3):e91581.

63. Hess R, Jaeschke A, Neubert H, Hintze V, Moeller S, Schnabelrauch M, et al. Synergistic effect of defined artificial extracellular matrices and pulsed electric fields on osteogenic differentiation of human mscs. Biomaterials. 2012;33(35):8975-85.

64. Meng S, Rouabhia M, Zhang Z, De D, De F, Laval U. Electrical stimulation in tissue regeneration. Appl Biomed Eng. 2011;23:37-62.

65. Sommer M, Kamm T, Tergau F, Ulm G, Paulus W. Repetitive paired-pulse transcranial magnetic stimulation affects corticospinal excitability and finger tapping in parkinson's disease. Clin Neurophysiol. 2002;113(6):944-50.

66. Waataja JJ, Tweden KS, Honda CN. Effects of high-frequency alternating current on axonal conduction through the vagus nerve. J Neural Eng. 2011; 8(5):056013.

67. Kim J, Yang HJ, Cho TH, Lee SE, Yong DP, Kim HM, et al. Enhanced regeneration of rabbit mandibular defects through a combined treatment of electrical stimulation and rhbmp-2 application. Med Biol Eng Comput. 2013;51(12):1339-48 
68. Babona-Pilipos R, Pritchard-Oh A, Popovic MR, Morshead CM. Biphasic monopolar electrical stimulation induces rapid and directed galvanotaxis in adult subependymal neural precursors. Stem Cell Res Ther. 2015;6(1):67.

69. Siegel D, Baca SM, Thompson DC, Huntsman MM, Mower MM, Ross D. The effect of anodal/cathodal biphasic electrical stimulation on insulin release. J Cell Physiol. 2019;234(9):16389-99.

70. Ercan B, Webster TJ. The effect of biphasic electrical stimulation on osteoblast function at anodized nanotubular titanium surfaces. Biomaterials. 2010;31(13):3684-93

71. Redouté JM, Browne D, Fitrio D, Lowery A, Kleeman L. A reduced data bandwidth integrated electrode driver for visual intracortical neural stimulation in $0.35 \mu \mathrm{m}$ mathcontainer loading mathjax high voltage CMOS. Microelectron J. 2013:44(4):277-82.

72. van dan Honert C, Mortimer JT. A technique for collision block of peripheral nerve: frequency dependence. IEEE Trans Biomed Eng. 1981;28(5):379-82.

73. Celik ME, Karagoz I. Comparison of monophasic and biphasic electrical stimulation by using temporal analysis for different inter-electrode spacings in the hexagonal arrays. Arab J Sci Eng. 2018;43(6):2889-98.

74. Yadollahpour A, Jalilifar M. Electromagnetic fields in the treatment of wound: a review of current techniques and future perspective. J Pure Appl Microbio. 2014;8(4):2863-77.

75. Esfandiari E, Roshankhah S, Mardani M, Hashemibeni B, Naghsh E, Kazemi M, et al. The effect of high frequency electric field on enhancement of chondrogenesis in human adipose-derived stem cells. Iran J Basic Med Sci. 2014;17(8):571-6.

76. Mardani M, Roshankhah S, Hashemibeni B, Salahshoor M, Naghsh E, Esfandiari E. Induction of chondrogenic differentiation of human adipose-derived stem cells by low frequency electric field. Adv Biomed Res. 2016;5(1):97.

77. Tzoneva R. Influence of electric field on cell behavior. Electrotreatment of cells for biomedical applications. Asian J Phys. 2014;23:789-814.

78. Ross CL. The use of electric, magnetic, and electromagnetic field for directed cell migration and adhesion in regenerative medicine. Biotechnol Prog. 2017;33(1):5-16.

79. Zohar B, Blinder Y, Mooney DJ, Levenberg S. Flow-induced vascular network formation and maturation in three-dimensional engineered tissue. ACS Biomater Sci Eng. 2017;4(4):1265-71.

80. Colosi C, Shin SR, Manoharan V, Massa S, Costantini M, Barbetta A, et al. Microfluidic bioprinting of heterogeneous $3 \mathrm{~d}$ tissue constructs using lowviscosity bioink. Adv Mater. 2016;28(4):677-84.

81. Min SK, Mi HL, Kwon BJ, Seo HJ, Koo MA, You KE, et al. Effects of direct current electric-field using ITO plate on breast cancer cell migration. Biomater Res. 2014;18(1):1-6.

82. Li YH, Huang GY, Zhang XH, Wang L, Du YA, Lu TJ, et al. Engineering cell alignment in vitro [J]. Biotechnol Adv. 2014;32(2):347-65.

83. Tai G, Tai M, Zhao M. Electrically stimulated cell migration and its contribution to wound healing [J]. Burns Trauma. 2018;6(1):20.

84. Shao SJ, Zhou SB, Li L, Li JR, Luo C, Wang JX, et al. Osteoblast function on electrically conductive electrospun pla/mwcnts nanofibers. Biomaterials. 2011:32(11):2821-33

85. Ko UH, Park S, Bang H, Kim M, Shin H, Shin JH. Promotion of myogenic maturation by timely application of electric field along the topographical alignment. Tissue Eng Part A. 2018;24(9-10):752-60.

86. Ganji Y, Li Q, Quabius ES, Böttner M, Selhuber-Unkel C, Kasra M. Cardiomyocyte behavior on biodegradable polyurethane/gold nanocomposite scaffolds under electrical stimulation. Mater Sci Eng C Mater Biol Appl. 2016;59:10-8.

87. Zhao Z, Qin L, Reid B, Pu J, Hara T, Zhao M. Directing migration of endothelial progenitor cells with applied dc electric fields. Stem Cell Res. 2012;8(1):38-48.

88. Banks TA, Luckman PSB, Frith JE, Cooper-White JJ. Effects of electric fields on human mesenchymal stem cell behaviour and morphology using a novel multichannel device. Integr Biol (Camb). 2015;7(6):693-712.

89. Hammerick KE, Longaker MT, Prinz FB. In vitro effects of direct current electric fields on adipose-derived stromal cells. Biochem Biophys Res Commun. 2010;397(1):12-7.

90. Chen C, Ruan S, Bai X, Lin C, Xie C, Lee I-S. Patterned iridium oxide film as neural electrode interface: biocompatibility and improved neurite outgrowth with electrical stimulation. Mater Sci Eng C. 2019;103:109865.

91. Long H, Yang G, Ma K, Xiao Z, Ren X. Effect of different electrical stimulation waves on orientation and alignment of adipose derived mesenchymal stem cells. Zhongguo Xiu Fu Chong Jian Wai Ke Za Zhi. 2017;31(7):853-61.
92. Feng JF, Liu J, Zhang XZ, Zhang L, Jiang JY, Nolta J, et al. Guided migration of neural stem cells derived from human embryonic stem cells by an electric field. Stem Cells. 2012;30(2):349-55.

93. Hoare II, Rajnicek AM, McCaig CD, Barker RN, Wilson HM. Electric fields are novel determinants of human macrophage functions. J Leukoc Biol. 2016; 99(6):1141-51.

94. Hayashi H, Edin F, Li H, Liu W, Rask-Andersen H. The effect of pulsed electric fields on the electrotactic migration of human neural progenitor cells through the involvement of intracellular calcium signaling. Brain Res. 2016; 1652:195-203.

95. Kumar A, Nune KC, Misra RD. Electric field-mediated growth of osteoblasts the significant impact of dynamic flow of medium. Biomater Sci. 2016;4(1): 136-44.

96. Canillas M, Moreno B, Chinarro E, Rajnicek AM. $\mathrm{TiO}_{2}$ surfaces support neuron growth during electric field stimulation. Mater Sci Eng C. 2017;79:1-8.

97. Zhao Z, Watt C, Karystinou A, Roelofs AJ, McCaig CD, Gibson IR, et al. Directed migration of human bone marrow mesenchymal stem cells in a physiological direct current electric field. Eur Cells Mater. 2011;22:344-58.

98. Guo A, Song B, Reid B, Gu Y, Forrester JV, Jahoda CA, et al. Effects of physiological electric fields on migration of human dermal fibroblasts. J Invest Dermatol. 2010;130(9):2320-7.

99. Yao L, Li YC, Knapp J, Smith P. Exploration of molecular pathways mediating electric field-directed schwann cell migration by RNA-seq. J Cell Physiol. 2015;230(7):1515-24.

100. Forciniti L, Ybarra J, Zaman MH, Schmidt CE. Schwann cell response on polypyrrole substrates upon electrical stimulation. Acta Biomater. 2014;10(6): 2423-33.

101. Iwasa SN, Babona-Pilipos R, Morshead CM. Environmental factors that influence stem cell migration: an "electric field". Stem Cells Int. 2017;2017: 4276927.

102. Zhao H, Steiger A, Nohner M, Ye H. Specific intensity direct current (DC) electric field improves neural stem cell migration and enhances differentiation towards $\beta$ iii-tubulin+ neurons. PLoS One. 2015;10(6): e0129625.

103. Liu J, Zhu B, Zhang G, Wang J, Tian W, Ju G, et al. Electric signals regulate directional migration of ventral midbrain derived dopaminergic neural progenitor cells via wnt/gsk3ß signaling. Exp Neurol. 2015;263:113-21.

104. Lo KY, Wu SY, Sun YS. A microfluidic device for studying the production of reactive oxygen species and the migration in lung cancer cells under single or coexisting chemical/electrical stimulation. Microfluid Nanofluid. 2016;20(1):15.

105. Jezierska-Wozniak K, Lipinski S, Huflejt M, Grabarczyk L, Barczewska M, Habich A, et al. Migration of human mesenchymal stem cells stimulated with pulsed electric field and the dynamics of the cell surface glycosylation. Adv Clin Exp Med. 2018;27(9):1181-93.

106. Dong ZY, Pei Z, Li Z, Wang YL, Khan A, Meng XT. Electric field stimulation induced neuronal differentiation of filum terminale derived neural progenitor cells. Neurosci Lett. 2017;651:109-15.

107. McKasson MJ, Huang L, Robinson KR. Chick embryonic schwann cells migrate anodally in small electrical fields. Exp Neurol. 2008;211(2):585-7.

108. Li YP, Xu T, Chen XM, Lin S, Cho M, Sun D, et al. Effects of direct current electric fields on lung cancer cell electrotaxis in a PMMA-based microfluidic device. Anal Bioanal Chem. 2017:409(8):2163-78.

109. Liu Q, Song B. Electric field regulated signaling pathways. Int J Biochem Cell B. 2014;55:264-8.

110. Gao RC, Zhang XD, Sun YH, Kamimura Y, Mogilner A, Devreotes PN, et al. Different roles of membrane potentials in electrotaxis and chemotaxis of dictyostelium cells. Eukaryot Cell. 2011;10(9):1251-6.

111. Zhao M, Penninger J, Isseroff RR. Electrical activation of wound-healing pathways. Adv Skin Wound Care. 2010;1(1):567-73.

112. Bai H, Forrester JV, Zhao M. DC electric stimulation upregulates angiogenic factors in endothelial cells through activation of VEGF receptors. Cytokine. 2011;55(1):110-5.

113. Cortese B, Palama IE, D'Amone S, Gigli G. Influence of electrotaxis on cell behaviour. Integr Biol (Camb). 2014;6(9):817-30.

114. Babona-Pilipos R, Droujinine IA, Popovic MR, Morshead CM. Adult subependymal neural precursors, but not differentiated cells, undergo rapid cathodal migration in the presence of direct current electric fields. PLoS One. 2011;6(8):e23808.

115. Hernández-Bule ML, Paíno CL, Trillo MÁ, Úbeda A. Electric stimulation at 448 $\mathrm{kHz}$ promotes proliferation of human mesenchymal stem cells. Cell Physiol Biochem. 2014;34(5):1741-55. 
116. Meng XT, Arocena M, Penninger J, Gage FH, Zhao M, Song B. PI3K mediated electrotaxis of embryonic and adult neural progenitor cells in the presence of growth factors. Exp Neurol. 2011;227(1):210-7.

117. Zhao M, Song B, Pu J, Wada T, Reid B, Tai G, et al. Electrical signals control wound healing through phosphatidylinositol-3-OH kinase- $\gamma$ and PTEN. Nature. 2006;442(7101):457-60

118. Babona-Pilipos R, Liu N, Pritchard-Oh A, Mok A, Badawi D, Popovic M, et al. Calcium influx differentially regulates migration velocity and directedness in response to electric field application. Exp Cell Res. 2018;368(2):202-14.

119. Kapeller B, Mueller J, Losert U, Podesser BK, Macfelda K. Microcurrent stimulation promotes reverse remodelling in cardiomyocytes. Esc Heart Failure. 2016;3(2):122-30.

120. Wang Y, Cui HT, Wu ZX, Wu NP, Wang ZL, Chen XS, et al. Modulation of osteogenesis in MC3T3-E1 cells by different frequency electrical stimulation. PLoS One. 2016;11(5):e0154924.

121. Naumova AV, Michel M, Anna M, Murry CE, Frank JA. Clinical imaging in regenerative medicine. Nat Biotechnol. 2014;32(8):804-18.

122. Zhao C, Tan A, Pastorin G, Han KH. Nanomaterial scaffolds for stem cell proliferation and differentiation in tissue engineering. Biotechnol Adv. 2013; 31(5):654-68.

123. Santos N, Cicuéndez M, Holz T, Silva V, Fernandes A, Vila M, et al. Diamondgraphite nanoplatelet surfaces as conductive substrates for the electrical stimulation of cell functions. ACS Appl Mat Interfaces. 2017;9(2):1331-42.

124. Dodel M, Nejad NH, Bahrami SH, Soleimani M, Amirabad LM, Hanaee-Ahvaz $H$, et al. Electrical stimulation of somatic human stem cells mediated by composite containing conductive nanofibers for ligament regeneration. Biologicals. 2017:46:99-107.

125. Li Y, Li X, Zhao R, Wang C, Qiu F, Sun B, et al. Enhanced adhesion and proliferation of human umbilical vein endothelial cells on conductive panipcl fiber scaffold by electrical stimulation. Mater Sci Eng C Mater Biol Appl. 2017;72:106-12

126. Zhu W, Ye T, Lee SJ, Cui H, Miao S, Zhou X, et al. Enhanced neural stem cell functions in conductive annealed carbon nanofibrous scaffolds with electrical stimulation. Nanomedicine. 2018;14(7):2485-94.

127. Snyder S, DeJulius C, Willits RK. Electrical stimulation increases random migration of human dermal fibroblasts. Ann Biomed Eng. 2017;45(9):204960.

128. Mamman HB, Adon M, Abdul JM. Optimization of electric field parameters for ht29 cell line towards wound healing application. Indian J Sci Technol. 2016;9(46):1-7.

129. Sun B, Tong W, Wang J, Li D, Jing W, Qiang G, et al. Polypyrrole-coated poly(l-lactic acid-co-e-caprolactone)/silk fibroin nanofibrous membranes promoting neural cells proliferation and differentiation with electrical stimulation. J Mater Chem B. 2016;4(41):6670-9.

130. Chan YC, Ting S, Lee YK, Ng KM, Zhang J, Chen Z, et al. Electrical stimulation promotes maturation of cardiomyocytes derived from human embryonic stem cells. J Cardiovasc Transl Res. 2013;6(6):989-99.

131. Hernández D, Millard R, Sivakumaran P, Wong RCB, Crombie DE, Hewitt AW, et al. Electrical stimulation promotes cardiac differentiation of human induced pluripotent stem cells. Stem Cells Int. 2016;2016:1718041.

132. Park SY, Park J, Sim SH, Sung MG, Kim KS, Hong BH, et al. Enhanced differentiation of human neural stem cells into neurons on graphene. Adv Mater. 2011;23(36):H263-7.

133. Creecy CM, O'Neill CF, Arulanandam BP, Sylvia VL, Navara CS, Bizios R. Mesenchymal stem cell osteodifferentiation in response to alternating electric current. Tissue Eng Part A. 2013;19(3-4):467-74

134. Zhang J, Neoh KG, Kang ET. Electrical stimulation of adipose-derived mesenchymal stem cells and endothelial cells co-cultured in a conductive scaffold for potential orthopaedic applications. J Tissue Eng Regen Med. 2018;12(4):878-89.

135. Matsumoto M, Imura T, Fukazawa T, Sun Y, Takeda M, Kajiume T, et al. Electrical stimulation enhances neurogenin2 expression through $\beta$-catenin signaling pathway of mouse bone marrow stromal cells and intensifies the effect of cell transplantation on brain injury. Neurosci Lett. 2013;533:71-6.

\section{Publisher's Note}

Springer Nature remains neutral with regard to jurisdictional claims in published maps and institutional affiliations.

Ready to submit your research? Choose BMC and benefit from:

- fast, convenient online submission

- thorough peer review by experienced researchers in your field

- rapid publication on acceptance

- support for research data, including large and complex data types

- gold Open Access which fosters wider collaboration and increased citations

- maximum visibility for your research: over $100 \mathrm{M}$ website views per year

At BMC, research is always in progress.

Learn more biomedcentral.com/submissions 